\title{
Reply to Meshkini et al.
}

\author{
Armin Zittermann $\mathbb{D}^{1} \cdot$ Heiner K. Berthold ${ }^{2} \cdot$ Stefan Pilz ${ }^{3}$
}

Received: 6 April 2021 / Revised: 12 April 2021 / Accepted: 16 April 2021 / Published online: 13 May 2021

(c) The Author(s) 2021. This article is published with open access

\section{To the Editor:}

Meshkini et al. [1] raised several issues regarding our meta-analysis [2]. With respect to the exclusion of specific age groups, we disagree that children should be deleted from data analysis. Fibroblast growth factor 23 (FGF-23) is a cardiovascular risk marker. Cardiovascular disease is a chronic illness and cardiovascular lesions can already occur during childhood and adolescence. Moreover, there are no major differences in vitamin D metabolism between adults and children at the average age included in our meta-analysis. Since we included only RCTs with a placebo group, each age group had its own control. Anyway, a sensitivity analysis with exclusion of studies including children did not alter our main findings (vitamin D effect on FGF-23: + $25 \mathrm{pg} / \mathrm{ml}$ [95\% CI: $15-34 \mathrm{pg} / \mathrm{mL}$; $P<0.001]$ ). Likewise, we are well aware that in case of several treatment groups the number of individuals in the control group has to be divided by the number of treatment groups, when analyzed in meta-analysis, and this is what we did. A subgroup analysis of studies with mean baseline circulating 25-hydroxyvitamin D concentrations below and above $50 \mathrm{nmol} / 1$ may indeed lead to misclassification of some individuals. Nevertheless, this kind of classification results in two clearly distinct subgroups and is thus an established methodological approach in case that individual participant data are not available. Notably, our results are in line with another meta-analysis,

$\triangle$ Armin Zittermann

azittermann@hdz-nrw.de

1 Clinic for Thoracic and Cardiovascular Surgery, Herz- und Diabeteszentrum NRW, Ruhr University Bochum, Bad Oeynhausen, Germany

2 Department of Internal Medicine and Geriatrics, Bethel Clinic (EvKB), Bielefeld, Germany

3 Division of Endocrinology and Diabetology, Department of Internal Medicine, Medical University of Graz, Graz, Austria which reported a significant increase in FGF-23 concentrations by vitamin $\mathrm{D}$ supplementation in individuals with initial 25-hydroxyvitamin D concentrations below $50 \mathrm{nmol} / \mathrm{l}[3]$.

Regarding missing of eligible RCTs for our meta-analysis, it is challenging to identify all relevant articles, given the large number of vitamin D publications each year and in particular if FGF-23 is not mentioned in the Abstract so that such articles are missed even by a properly performed systematic literature search. Of the six additional studies mentioned by Meshkini et al., two [4, 5] did not provide all baseline or in-study data that were needed for our metaanalysis. Inclusion of the other four studies [6-9] does not substantially change our overall results (vitamin $D$ effect on FGF-23: $+19 \mathrm{pg} / \mathrm{ml}$ [95\% CI: $14-25 \mathrm{pg} / \mathrm{mL} ; P<0.001]$ ) and thus further strengthens the reliability of our metaanalysis. However, we very much appreciate that Meshkini et al. pointed to a misclassification by us of daily vitamin D dosing in the included study by Trummer et al. (2800 IU daily instead of 2000 IU daily) [10]. We apologize for this mistake and re-analyzed and re-classified our data (subgroups: daily vitamin D dose equivalent up to $3000 \mathrm{IU}$; daily vitamin $\mathrm{D}$ dose equivalent $>3000$ IU daily; administration of activated vitamin D) and also included the four aforementioned studies by Meshkini et al. [6-9]. The results remain similar to the ones of our article [2] (vitamin D dose equivalent $\leq 3000$ IU/day: $+1 \mathrm{pg} / \mathrm{ml}$ [95\% CI: $1-2 \mathrm{pg} / \mathrm{ml}$; vitamin D dose equivalent $>3000$ IU/day: $+16 \mathrm{pg} / \mathrm{ml}[95 \%$ CI: $4-28 \mathrm{pg} / \mathrm{ml}$ ]; administration of activated vitamin D: $+67 \mathrm{pg} / \mathrm{ml}$ [95\% CI: $16-117 \mathrm{pg} / \mathrm{ml}] ; \quad P_{\text {interaction }}<0.001$ ), except that our re-analysis now shows that daily vitamin D doses up to $3000 \mathrm{IU}$ instead of up to $2000 \mathrm{IU}$ vitamin D daily do not result in a substantial change in FGF-23.

Altogether, the vitamin D dose re-classification in one study results in the new conclusion that vitamin doses up to 3000 IU daily do not influence FGF-23 concentrations. However, all of our other conclusions do not change substantially so that the reliability of our main findings is further supported by the additional analyses due to the comments raised by Meshkini et al. 
Funding Open Access funding enabled and organized by Projekt DEAL.

\section{Compliance with ethical standards}

Conflict of interest The authors declare no competing interests.

Publisher's note Springer Nature remains neutral with regard to jurisdictional claims in published maps and institutional affiliations.

Open Access This article is licensed under a Creative Commons Attribution 4.0 International License, which permits use, sharing, adaptation, distribution and reproduction in any medium or format, as long as you give appropriate credit to the original author(s) and the source, provide a link to the Creative Commons license, and indicate if changes were made. The images or other third party material in this article are included in the article's Creative Commons license, unless indicated otherwise in a credit line to the material. If material is not included in the article's Creative Commons license and your intended use is not permitted by statutory regulation or exceeds the permitted use, you will need to obtain permission directly from the copyright holder. To view a copy of this license, visit http://creativecommons. org/licenses/by/4.0/.

\section{References}

1. Meshkini F, Soltani S, Clayton ZS, Abdollahi S. Letter to the editor on the article "The effect of vitamin D on fibroblast growth factor 23: a 2 systematic review and meta-analysis of randomized controlled trials".

2. Zittermann A, Berthold HK, Pilz S. The effect of vitamin D on fibroblast growth factor 23: a systematic review and meta-analysis of randomized controlled trials. Eur J Clin Nutr. 2020. https://doi. org/10.1038/s41430-020-00725-0.

3. Charoenngam N, Rujirachun P, Holick MF, Ungprasert P. Oral vitamin D3 supplementation increases serum fibroblast growth factor 23 concentration in vitamin D-deficient patients: a systematic review and meta-analysis. Osteoporos Int. 2019;30:2183-93.

4. Alvarez JA, Law J, Coakley KE, Zughaier SM, Hao L, Shahid Salles K, et al. High-dose cholecalciferol reduces parathyroid hormone in patients with early chronic kidney disease: a pilot, randomized, double-blind, placebo-controlled trial. Am J Clin Nutr. 2012;96:672-9.

5. Larsen T, Mose FH, Bech JN, Pedersen EB. Effect of paricalcitol on renin and albuminuria in nondiabetic stage III-IV chronic kidney disease: a randomized placebo-controlled trial. BMC Nephrol. 2013;14:163.

6. Bhan I, Dobens D, Tamez H, Deferio JJ, Li YC, Warren HS, et al. Nutritional vitamin D supplementation in dialysis: a randomized trial. Clin J Am Soc Nephrol. 2015;10:611-9.

7. Larsen T, Mose FH, Bech JN, Hansen AB, Pedersen EB. Effect of cholecalciferol supplementation during winter months in patients with hypertension: a randomized, placebo-controlled trial. Am J Hypertens. 2012;25:1215-22.

8. Turrini F, Scarlini S, Giovanardi P, Messora R, Roli L, Chester J, et al. Effects of cholecalciferol supplementation in patients with stable heart failure and low vitamin D levels (ECSPLOIT-D): a doubleblind, randomized, placebo-controlled pilot study. Minerva Cardioangiol. 2017;65:553-62.

9. Sprague SM, Crawford PW, Melnick JZ, Strugnell SA, Ali S, Mangoo-Karim R, et al. Use of extended-release calcifediol to treat secondary hyperparathyroidism in stages 3 and 4 chronic kidney disease. Am J Nephrol. 2016;44:316-25.

10. Trummer C, Schwetz V, Pandis M, Grübler MR, Verheyen N, Gaksch M, et al. Effects of vitamin D supplementation on FGF23: a randomized-controlled trial. Eur J Nutr. 2019;58:697-703. 